\title{
Assessment of Some Wetland Potentials in Makurdi Supporting Rice and Sugarcane Production
}

\author{
Usman, J. ${ }^{1}$ Ogbu, J.O. ${ }^{2}$ lji, S.E. ${ }^{3}$ and Afatar, S. ${ }^{4}$ \\ ${ }^{1-4}$ Department of Soil Science, Federal University of Agriculture Makurdi, Benue State, Nigeria
}

Jakusman05@gmail.com

Keywords: Characterization, Classification, Wetland, Suitability evaluation, Rice and sugarcane production.

\begin{abstract}
The study was carried out in Makurdi, Benue State with the view to characterize some wetlands of Makurdi area and their suitability to rice and sugarcane production. In order to characterize and classify the soil, four pedons were dug at the selected seasonally flooded wetlands. The soils were characterized in terms of their morphological, physical and chemical properties. The soils were generally sandy loam, loamy sands and sandy clay loam. The distribution of clay content increased with soil depth for all pedons. The soils were strongly to moderately acid in reaction (3.47 to 5.61$)$ in $\mathrm{H}_{2} \mathrm{O}$. The soils had low $(0.2$ to $3.77 \mathrm{~g} / \mathrm{kg})$ organic carbon. The percentage base saturation ranged from 5 to $75 \%$. The soils were classified as Vertic Endoaquepts/Vertic Gleysols (Orthoeutric), Aeric Glossaqualfs/Lixic Gleysols (Orthoeutric) and Typic Epiaquults/Ferralic Acrisols (Epidystric). Soil Type B was marginally suitable (S3) for sugarcane. However, all the 4 soil types were moderately suitable (S2) for rice.
\end{abstract}

\section{Introduction}

Wetlands were mostly regarded as waste lands and a den of pests and diseases. Eventually, their potentials were gradually discovered. The discovery reveals high relevance for provision of food and shelter, not to mention tourism. It is established that wetlands are among the most important ecosystems on earth. The study of wetlands is called Telmatology. Their studies have revealed that the critical role they play rightly describes them as "Kidneys of the landscape". This is because they function as downstream receivers of water and waste. Other researchers described them as "biological supermarkets" because of the extensive food chain and rich biodiversity they support (Isirimah, 2002). Akanmigbo (2002) did an extensive survey of wetlands and identified eight orders of the Soil Taxonomy (Soil Survey Staff, 1997) which he correlated them with the FAO-UNESCO system (1974) and stated many of their potential uses. Odingo (1991) however stated that land use in Africa is extensively influenced by ecological conditions and patterns of use as by previous generations.

Man's land use activities on wetlands have continued to increase in proportion to his awareness. Some of these activities have been identified as harmful and alters the ecosystem. These necessitate the application of effective land use planning of wetlands by relevant stakeholders through survey and satisfied community needs for safe housing, public infrastructure, conserve the ecosystem and for economic development (Hames et al., 2014). Studies on soil classification and soil wetland use in the extensive agricultural soils in Makurdi north, Nigeria are scarce.

Also, a good knowledge of the soil qualities in Makurdi is not only desirable for increased rice and sugarcane yield, but also could lead to effective farm management system that would ensure sustainability of rice and sugarcane production. The suitability evaluation of these soils, which could indicate the kinds and extent of soil limitation that impedes rice and sugarcane production in the study area is therefore required. Such adequate information about the soil properties and management would provide practical approaches for ameliorating the soils physical, morphological and chemical limitations for the enhancement of rice and sugarcane production. This however necessitates the present study with the specific objective of characterizing, classifying and 
recommending appropriate management measures aimed at enhancing rice and sugarcane production.

\section{Materials and Methods}

\section{Site Description}

The study was carried out in selected wetlands of Makurdi north located in Makurdi Local Government Area of Benue State. Makurdi lies within latitudes $7^{0} 41^{\prime}$ and $7^{0} 46^{\prime} \mathrm{N}$ and longitude $8^{0} 29^{\prime}$ and $8^{0} 35^{\prime} \mathrm{E}$ (FDALR, 1990). The study was confined to the north bank of river Benue which is low-lying at about $300 \mathrm{~m}$ above mean sea level (Offodile, 1974 and land and survey, 2015). The low level topography encourages the development of wetland soils through floods and high water table. The soils dry up for a period of 2 to 3 months a year but only at the surface for most of them.

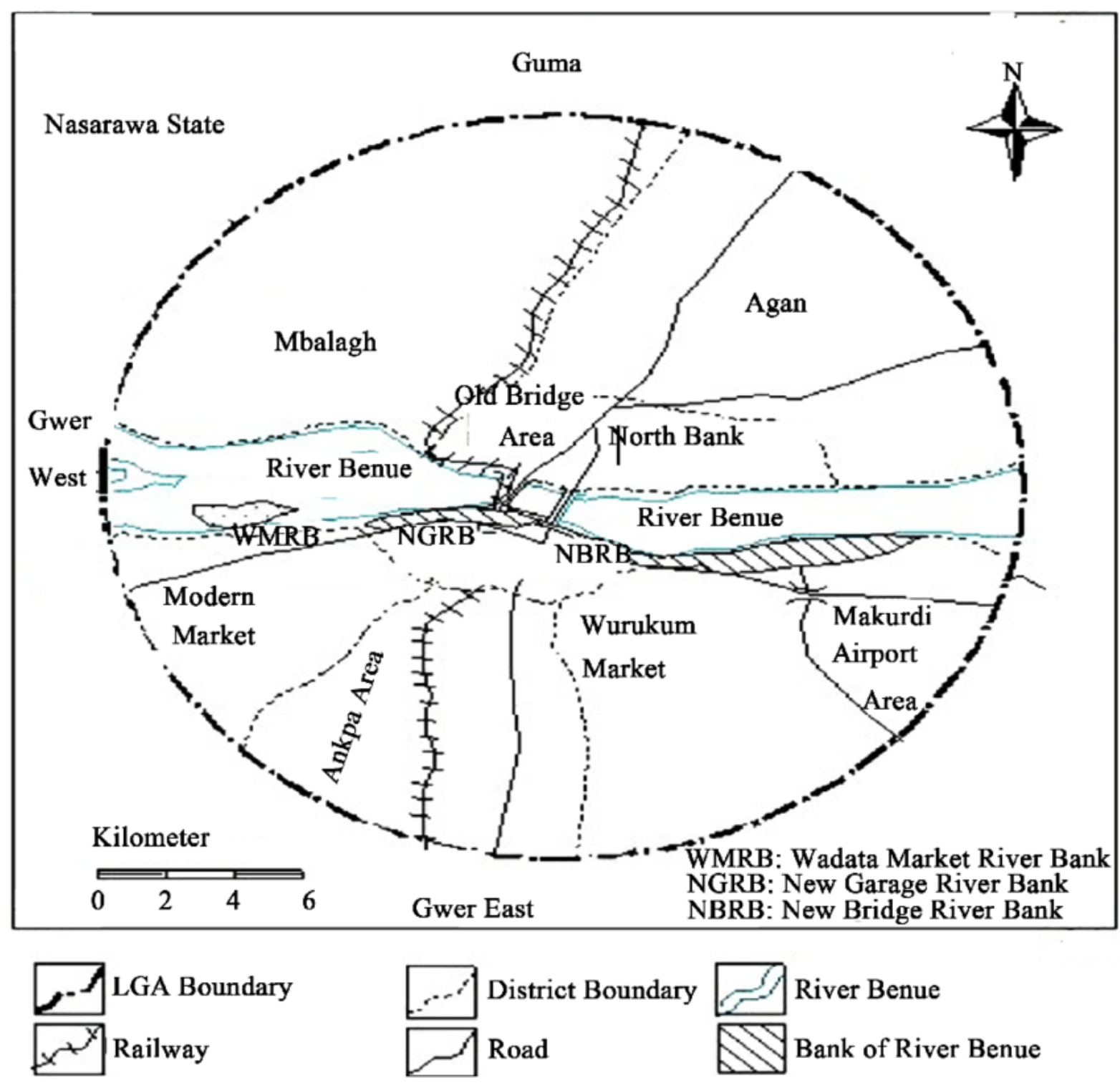

Source: https://www.google.com/imgres

Figure 1: Map of Makurdi LGA showing the study area

The climate of the area is hot and humid tropic type with distinct wet and dry seasons. The monthly temperature ranged from $24.5^{\circ} \mathrm{C}$ to $30.3^{\circ} \mathrm{C}$. Annual rainfall ranged from $1100 \mathrm{~mm}$ to about $2000 \mathrm{~mm}$, and its distribution is characterized by two peak periods (July and September) separated by a short August break (Adamgbe and Ujoh, 2012). Sunshine hours are high between January to 
April and decreases between May through to October because of the effect of cloud. There is a noticeable increase in sunshine hour again by November.

\section{Field Work}

Soil profiles pits were dug at the most representative points of observation representing the various strata of the wetlands. The soil profiles were described according to the USDA Soil Survey Staff, (1999) guidelines. Soil samples were taken from the different horizons of the profile pits for routine physical and chemical analysis and other fertility indices.

\section{Laboratory Analysis}

The soil samples collected from the field were air-dried, gently crushed and sieved. The particle size distribution (PSD) was determined by Buoyoucos hydrometer method as described by Day (1965). Soil reaction $(\mathrm{pH})$ was determined by the electrometric method in 1:1 soil: water ratio as described by Hesse (1971), and organic carbon was determined by the Walkley-Black method as described by Hesse (1971). The Macro Kjeldahl method was used to analyze for total N, while the Bray I method as described by IITA (1979) was used to analyze for available P. Exchangeable cations $(\mathrm{Ca}, \mathrm{Mg}, \mathrm{K}, \mathrm{Na})$ were determined from $\mathrm{NH}_{4} \mathrm{OAC}$ filtrate. Exchange acidity was determined using the Barium chloride-triethanolamine method as described by Peech (1965). Effective cation exchange capacity (ECEC) was calculated by the summation of the exchangeable bases and exchangeable acidity while the percentage base saturation was equally calculated by dividing the sum of exchangeable bases over the effective cation exchange capacity and multiplying by 100 .

Table 1: Suitability Requirement for Rice

\begin{tabular}{|c|c|c|c|c|c|c|c|}
\hline $\begin{array}{l}\text { Land qualities } \\
\text { Factors Rating }\end{array}$ & $\begin{array}{l}\text { Land } \\
\text { characteristics }\end{array}$ & $\begin{array}{l}\text { Unit } \\
\%\end{array}$ & $\begin{array}{l}\text { S1 } \\
100-85\end{array}$ & $\begin{array}{l}\text { S2 } \\
84-60\end{array}$ & $\begin{array}{l}\mathrm{S} 3 \\
59-40\end{array}$ & $\begin{array}{l}\text { N1 } \\
39-20\end{array}$ & $\begin{array}{l}\mathrm{N} 2 \\
19-0\end{array}$ \\
\hline Climate $(c)^{4}$ & $\begin{array}{l}\text { Annual Rainfall } \\
\text { Solar radiation }\end{array}$ & $\begin{array}{l}\text { Mm } \\
\text { Cal. } \\
\text { day }^{-1}\end{array} \quad \mathrm{~cm}^{-2}$. & $\begin{array}{l}>1400 \\
>300\end{array}$ & $\begin{array}{l}1200- \\
1400 \\
300-200\end{array}$ & $\begin{array}{l}950- \\
1100 \\
200-100\end{array}$ & $\begin{array}{l}850- \\
900 \\
<100\end{array}$ & $\begin{array}{l}<850 \\
\text { any }\end{array}$ \\
\hline Growing Period ${ }^{2} 3$ & LPG+ & Days & $\begin{array}{l}120- \\
180\end{array}$ & $70-120$ & $>70$ & $<70$ & $<70$ \\
\hline $\begin{array}{l}\text { Soil physical } \\
\text { characteristics }\end{array}$ & $\begin{array}{l}\text { Soil Depth14 } \\
\text { Clay21 }\end{array}$ & $\begin{array}{l}\mathrm{cm} \\
\%\end{array}$ & $\begin{array}{l}>20 \\
40-25\end{array}$ & $\begin{array}{l}10-20 \\
25-15\end{array}$ & $\begin{array}{l}5-10 \\
15-5\end{array}$ & $\begin{array}{l}<5 \\
\leq 15 ; \geq 5\end{array}$ & $\begin{array}{l}\text { any } \\
\text { any }\end{array}$ \\
\hline Wetness (w)4 & $\begin{array}{l}\text { Drainage } \\
\text { S.W.D } \\
\text { F.D } \\
\text { G.W.T }\end{array}$ & $\begin{array}{l}- \\
\mathrm{cm} \\
\text { months } \\
\mathrm{cm}\end{array}$ & $\begin{array}{l}1-3 \\
10-20 \\
>4 \\
0-15\end{array}$ & $\begin{array}{l}1-3 \\
20-40 \\
3-4 \\
15-30\end{array}$ & $\begin{array}{l}3 \\
40-60 \\
2-3 \\
30-60\end{array}$ & $\begin{array}{l}\text { any } \\
>60 ; \\
<10 \\
>2 ;>4 \\
>60\end{array}$ & $\begin{array}{l}\text { any } \\
\text { any } \\
\text { any } \\
\text { any }\end{array}$ \\
\hline Fertility Status (f) & $\begin{array}{l}\mathrm{pH}^{19} \\
\text { total N } \\
\text { organic carbon } \\
\mathrm{P}(\text { Bray })^{18} \\
\mathrm{P}(\text { Olsen })^{20} \\
\mathrm{~K}^{20} \\
\mathrm{Ca}^{20} \\
\mathrm{Mg}^{20} \\
\mathrm{CEC}(\text { soil })^{20}\end{array}$ & $\begin{array}{l}- \\
\% \\
\% \\
\text { Mg.kg-1 } \\
\text { Mg.kg-1 } \\
\text { Cmol.kg-1 } \\
\text { Cmol.kg-1 } \\
\text { Cmol.kg-1 }\end{array}$ & $\begin{array}{l}5.5-7.5 \\
>0.2 \\
2-3 \\
>20 \\
>10 \\
>0.2 \\
10-15 \\
2-5 \\
>16\end{array}$ & $\begin{array}{l}5.2-5.5 \\
0.1-0.2 \\
1-2 \\
15-20 \\
7.5-10 \\
0.1-0.2 \\
5-10 \\
1-2 \\
10-16\end{array}$ & $\begin{array}{l}\leq 5.2 \\
\geq 8.2 \\
0.05- \\
0.1 \\
3-4 \\
10-15 \\
5-7.5 \\
<0.1 \\
1-5 \\
<1 \\
5-10\end{array}$ & $\begin{array}{l}\leq 5.2, \\
\geq 8.2 \\
<0.05 \\
>4 ; \leq 1 \\
<10 \\
<5 \\
<0.1 \\
<1 ;>5 \\
<1 ;>5 \\
<5\end{array}$ & $\begin{array}{l}\text { any } \\
\text { any } \\
\text { any } \\
\text { any } \\
\text { any } \\
\text { any } \\
\text { any } \\
\text { any } \\
\text { any }\end{array}$ \\
\hline
\end{tabular}

Sources: Modified from Sys (1985)

Key:

S.W.D = Surface Water Depth

F.D = Flooding Duration

G.W.T $=$ Ground Water Table

1= Imperfect, $2=$ Moderate; Poor, $3=$ Very Poor; + LPG $=$ Length of Growing Periods 
Table 2: Suitability Requirement for Sugarcane

\begin{tabular}{|c|c|c|c|c|c|c|}
\hline \multicolumn{2}{|c|}{$\begin{array}{c}\text { Site characteristics } \\
\text { Climate regime }\end{array}$} & \multicolumn{5}{|c|}{ Rating } \\
\hline Cliı & nate regime & Unit & $\begin{array}{c}\text { Highly } \\
\text { suitable } \\
\text { S1 }\end{array}$ & $\begin{array}{l}\text { Moderately } \\
\text { suitable S2 }\end{array}$ & $\begin{array}{l}\text { Marginally } \\
\text { suitable S3 }\end{array}$ & $\begin{array}{c}\text { Not } \\
\text { suitable } \\
\text { N }\end{array}$ \\
\hline & $\begin{array}{l}\text { Mean temperature } \\
\text { growing season }\end{array}$ & ${ }^{0} \mathrm{C}$ & $30-34$ & $\begin{array}{l}26-29 \\
35-38\end{array}$ & $\begin{array}{l}25-20 \\
39-40\end{array}$ & $\begin{array}{l}<20 \\
>40\end{array}$ \\
\hline & $\begin{array}{l}\text { Mean minimum } \\
\text { temperature } \\
\text { growing season }\end{array}$ & ${ }^{0} \mathrm{C}$ & $10-20$ & $21-30$ & $9-5$ & $<5$ \\
\hline & Mean RH (\%) & $\begin{array}{l}\text { Growing } \\
\text { season }\end{array}$ & $>0-85$ & $\begin{array}{l}60-70 \\
85-90\end{array}$ & $60-50$ & $<50$ \\
\hline & & $\begin{array}{l}\text { Ripening } \\
\text { season }\end{array}$ & $55-76$ & $75-90$ & $>55,>90$ & \\
\hline $\begin{array}{l}\text { Land } \\
\text { quality }\end{array}$ & Land characteristic & & & & & \\
\hline $\begin{array}{l}\text { Oxygen } \\
\text { availability } \\
\text { to roots }\end{array}$ & Soil drainage & Class & $\begin{array}{l}\text { Well } \\
\text { drained }\end{array}$ & $\begin{array}{l}\text { Moderating } \\
\text { drained }\end{array}$ & Poorly drained & $\begin{array}{l}\text { Very } \\
\text { poorly } \\
\text { drained }\end{array}$ \\
\hline & Depth of water & $\mathrm{M}$ & $>1.0$ & $1.0-0.5$ & $<0.5$ & \\
\hline $\begin{array}{l}\text { Nutrient } \\
\text { availability }\end{array}$ & Texture & Class & $\begin{array}{l}\text { L, cl, sil, } \\
\text { Sicl, sc, } \\
\text { scl }\end{array}$ & $\mathrm{C}(\mathrm{m} / \mathrm{k}), \mathrm{sl}$ & $\mathrm{Cl}$ (ss) & \\
\hline & $\mathrm{pH}$ & $1: 2.5$ & $\begin{array}{c}>0- \\
8.0\end{array}$ & $\begin{array}{c}6.0-6.9 \\
8.1-9.0\end{array}$ & $\begin{array}{l}4.0-5.9 \\
9.1-9.5\end{array}$ & $\begin{array}{l}<4.0 \\
>9.5\end{array}$ \\
\hline $\begin{array}{l}\text { Rooting } \\
\text { conditions }\end{array}$ & $\begin{array}{l}\text { Effective } \\
\text { depth }\end{array}$ & $\mathrm{Cm}$ & $>100$ & $100-75$ & $>5-50$ & $<50$ \\
\hline $\begin{array}{l}\text { Erosion } \\
\text { hazard }\end{array}$ & Slope & $\%$ & $<3$ & $3-5$ & $5-8$ & $>8$ \\
\hline
\end{tabular}

Source: Naida (1999)

NB: Clay $(\mathrm{m} / \mathrm{k})=$ mixed kaolinite : Clay $(\mathrm{ss})=$ shrink - swell clays

Texture: 1 = loam, sil = silty loam, sicl $=$ silty clay, $\mathrm{sc}=$ sandy clay, $\mathrm{scl}=$ sandy clay loam

Table 3: Suitability Class Scores of the Profiles in the Study Area for Rice and Sugarcane

\begin{tabular}{|c|c|c|c|}
\hline Soil type & Suitable & Major limitation & Fertility management \\
\hline Soil type A Profile 1 & $\begin{array}{l}\text { Rice (S2) } \\
\text { Sugarcane (S3) }\end{array}$ & $\begin{array}{l}\text { Drainage is poor }>4 \\
\text { months, pH is low } \\
(4.73) \mathrm{GWT} \text { is too high } \\
\text { for sugarcane }<30 \mathrm{~cm}\end{array}$ & $\begin{array}{l}\text { Liming addition of FYM } \\
\text { and judicious use of } \\
\text { fertilizers }\end{array}$ \\
\hline Soil type A profile 2 & $\begin{array}{l}\text { Rice (S2) } \\
\text { Sugarcane (S3) }\end{array}$ & $\begin{array}{l}\text { Drainage is poor }>4 \\
\text { months, pH is low } \\
(4.73) \mathrm{GWT} \text { is too high } \\
\text { for sugarcane }<30 \mathrm{~cm}\end{array}$ & $\begin{array}{l}\text { Liming and judicious use } \\
\text { of fertilizer }\end{array}$ \\
\hline Soil type B Profile 3 & $\begin{array}{l}\text { Rice (S2) } \\
\text { Sugarcane (S3) }\end{array}$ & $\begin{array}{l}\mathrm{pH} \text { is low for sugarcane } \\
(5.21) \text { fertility is very } \\
\text { low \% BS is }>50 \\
\text { me/ } 100 \mathrm{~g}\end{array}$ & $\begin{array}{l}\text { Liming, poultry manure, } \\
\text { FYM, Judicious fertilizer } \\
\text { use }\end{array}$ \\
\hline Soil type B Profile 4 & $\begin{array}{l}\text { Rice (S2) } \\
\text { Sugarcane (S3) }\end{array}$ & $\begin{array}{l}\mathrm{pH} \text { is low for sugarcane } \\
(5.21) \text { fertility is very } \\
\text { low \% BS is }>50 \\
\mathrm{me} / 100 \mathrm{~g}\end{array}$ & $\begin{array}{l}\text { Liming, poultry manure, } \\
\text { FYM, Judicious fertilizer } \\
\text { use }\end{array}$ \\
\hline
\end{tabular}

$\overline{S 2}=$ moderately suitable, $S 3=$ marginally suitable, $F Y M=$ farm yard manure, $G W T=$ ground water table 


\section{Results and Discussions}

\section{Soil Morphological Characteristics}

The morphological characteristics of the soils are presented in Table 3. The soils were deep ranging from 145 to $186 \mathrm{~cm}$. Surface soil textures were generally sandy clay loam to sandy loam, while the subsurfaces varied from sandy clay loam, sandy loam to sandy clay. Generally, the soils were poorly drained as indicated by the presence of mottles in the surface horizons and gleyed lower horizons. The poor drainage could be due to the accumulation of surface water as a result of the depressional landscape as well as the high clay fraction of the soils. The soils include dark greyish brown (10YR4/2) Sandy clay loam; pale brown (10YR6/3); brownish yellow (10YR6/6); dark brown (7.5YR4/2) loam; gray (7.5YR6/1) sandy loam; pinkish gray (7.5YR6/2) sandy loam; to pink (7.5YR8/3) sandy clay. Soils of profiles 2 had predominantly dark brown (7.5YR4/2 moist) colour in its A horizon. This could be attributed to the presence of relatively high O.M which is the main colouring agent in the top soil (Ufot, 2012, Brandy, and Weil, 2014).

\section{Physical Characteristics}

Table 5 shows the physical properties of soils of the study area. The clay content ranged from 7.2 to $36.1 \%$. The clay content increased with depth in all profiles which may be as a result of some pedogenic processes such as lessivage, eluviation and illuviation which indicates the presence of argillic or kandi sub-surface diagnostic horizons. However, over a very long period of time, pedogenetic processes such as erosion, deposition, eluviations, and weathering can change the soil texture (Foth, 1990; Brady and Weil, 2002). The relative differences in clay content among the soil units could be due to slight differences in topography and cultivation. This could also be due to the alluvial parent materials as well as the nature of the underlying geology. The sand fraction of the soil ranged from $47.5 \%$ to $77.9 \%$. It decreased with depth in all the Profile except profile 1 which decreased gradually but increased slightly in the fourth horizon. The silt content increased or decreased irregularly with depth. This may be attributed to the differences in relief and the rate of deposition of accumulated materials brought down from the upper slope by fluvial processes into the depressional lowland. A similar observation was made by Miura et al., (1997). The very low silt content $(9.2-14.1 \% \%)$ of profiles 1 may be due to excessive washing away of the soil particles by water erosion and runoff (Idoga, 2012). The soils were well developed, having structures which were commonly moderate to strong medium subangular blocky, moderate to strong coarse subangular blocky with exception of profile 1 at B horizon which had strong platy and profile 3 and 4 which had moderate medium granular structure at the Ap horizon. The good structural development could have been influenced by the high clay content of the soils.

\section{Chemical Characteristics}

Soil chemical properties are presented in Table 5 . The soils were strongly to moderately acid in reaction with $\mathrm{pH}$ values ranging from 3.47 to 5.61 in $\mathrm{H}_{2} \mathrm{O}$. Soil $\mathrm{pH}$ in the surface horizons was lowest (4.56) in profile 1 and highest (5.43) in profile 3. This may be due to factors such as return of bases to the soil through recycling by plants and the deposition of nutrients carried in solution from surface wash or lateral flow from relatively higher landscape (Ibang et al., 2005). Idoga and Azagaku, (2005) also attributed this to nutrient biocycling and high percentage base saturation at the surface horizon. It could also be accounted for by the direct deposition of crop and vegetable residues on the soil surface and their subsequent decomposition to release basic cations to the soil. The higher acidity in the subsurface horizons may be as a result of leaching of cations from the top soils. The organic carbon was high while the total nitrogen was low $\left(9.5\right.$ and $\left.1.05 \mathrm{gkg}^{-1}\right)$. Organic carbon content of the soils decreased with profile depth from $3.77 \%$ in the surface horizon to $0.20 \%$ in the subsurface horizon. The high amount of organic carbon may be attributed to the incorporation of plant and animals residues to the soil. The low amount of organic carbon may probably due to continue cropping for long period, bush burning, high erosive rate, grazing, harvested crop residues without replacement and very poor management activities. The low level of $\mathrm{N}$ in the soils may be attributed to release from plant tissues, gaseous loss, surface runoff, leaching, 
climatic factors, vegetation, human activities, initial soil $\mathrm{pH}$ and low activities of symbiotic and non-symbiotic $\mathrm{N}$-fixing bacteria. Loss of $\mathrm{N}$ through denitrification and volatilization may also contribute to the low level of $\mathrm{N}$ in the area. Available $\mathrm{P}$ was rated low to high with values ranging from 1.90 to $28.88 \mathrm{mgkg}^{-1}$. This may be due to strong adsorption of this nutrient by the soil colloids (Kubrin et al., 2000). The low amount of available P may also be attributed to the low pH level which fixed the $\mathrm{P}$ and make it unavailable.

Exchangeable bases $(\mathrm{Ca}, \mathrm{Mg}, \mathrm{K}$ and $\mathrm{Na})$ were low in all the soil units. Calcium was the most prevalent cation on the exchange complex with values ranging from 0.07 to $3.83 \mathrm{cmolkg}^{-1}$. The low exchangeable bases of these soils may be due to the underlying materials, intensity of weathering, leaching, low activity clay, very low organic matter content and the lateral translocation of bases (Krasilinikoff et al., 2002; Kang and Balasubramanian, 1990; Kang, 1993). ECEC values of the soils varied from $1.31 \mathrm{cmolkg}^{-1}$ in the subsurface horizon to $5.24 \mathrm{cmolkg}^{-1}$ in the surface. This is rated low to moderate (FAO, 1983). ECEC values were high $\left(5.24 \mathrm{cmolkg}^{-1}\right)$ in the surface horizons with a slight decrease in the subsurface of all the profile except profile 3 which had an increase at lower depth. The surface values could be attributed to the influence of soil organic matter content, while those of the lower horizons may be as a result of the contribution of clay (Idoga and Azagaku, 2005). Percentage base saturation values for profile 1 and 2 soils were high (64 to $78 \%$ ) while those of profile 3 and 4 soils were low ranging (4 to $55 \%$ ). Therefore, as the base saturation were above $50 \%$ in the cases of profile 1 and 2, the soils have high fertility potential while those of profile 3 and 4 were low implying low fertility (which forms the separating index between fertile soils and non fertile soils as stated by Landon, 1984). The percentage base decreased with depth in all the profiles which could be attributed to the active plant litter decomposition process which incorporate cations from the litter into the soil surface (Malgwi, 1979).

Table 4: Morphological Description of the Study Area

\begin{tabular}{|c|c|c|c|c|c|c|c|c|}
\hline \multirow[t]{2}{*}{ Horizon } & \multirow{2}{*}{$\begin{array}{l}\text { Depth } \\
\text { (cm) }\end{array}$} & \multicolumn{2}{|c|}{ Munsell soil colour } & \multirow[t]{2}{*}{ Mottles } & \multirow[t]{2}{*}{ Texture } & \multirow[t]{2}{*}{ Structure } & \multirow[t]{2}{*}{ Boundary } & \multirow[t]{2}{*}{ Consistence } \\
\hline & & Moist & Dry & & & & & \\
\hline \multicolumn{9}{|c|}{ Soil type A: Profile 1: Vertic Endoaquepts/Vertic Gleysols (Orthoeutric) } \\
\hline A & $0-12$ & $10 \mathrm{YR} 4 / 2$ & $10 \mathrm{YR} 7 / 2$ & & $\begin{array}{l}\text { Sandyclay } \\
\text { loam }\end{array}$ & $3 \mathrm{msbk}$ & As & mpsw \\
\hline A & $12-40$ & $10 Y R 4 / 2.5$ & $10 \mathrm{YR} 7 / 2$ & & $\begin{array}{l}\text { Sandyclay } \\
\text { loam }\end{array}$ & $3 \mathrm{pl}$ & Aw & mpsw \\
\hline $\mathrm{B}$ & $40-116$ & $10 \mathrm{YR} 6 / 3$ & $10 \mathrm{YR} 7 / 2$ & $\mathrm{f} 2 \mathrm{f}(7.5 \mathrm{YR} 5 / 6)$ & $\begin{array}{l}\text { Sandyclay } \\
\text { loam }\end{array}$ & $2 \mathrm{csbk}$ & $\mathrm{Cw}$ & mpsw \\
\hline $\mathrm{BC}$ & $\begin{array}{l}116- \\
178\end{array}$ & $10 \mathrm{YR} 6 / 6$ & 10YR7/3 & $\mathrm{m} 2 \mathrm{~d}(5 \mathrm{YR} 4 / 6)$ & $\begin{array}{l}\text { Sandyclay } \\
\text { loam }\end{array}$ & $3 \mathrm{csbk}$ & - & mpsw \\
\hline \multicolumn{9}{|c|}{ Soil Type A: Profile 2: Typic Glossiaqualfs/Lixic Gleysols (Orthoeutric) } \\
\hline A & $0-11$ & 7.5YR4/2 & 7.5YR7/1 & & Loam & $3 \mathrm{msbk}$ & As & mpsw \\
\hline $\mathrm{Bt}_{1}$ & $11-70$ & $7.5 \mathrm{YR} 4 / 2$ & $7.5 \mathrm{YR} 7 / 1$ & c1f(10YR5/) & $\begin{array}{l}\text { Sandyclay } \\
\text { loam }\end{array}$ & $3 \mathrm{msbk}$ & $\mathrm{Cl}$ & vpsw \\
\hline $\mathrm{Ct}_{2}$ & $70-160$ & $7.5 \mathrm{YR} 6 / 1$ & $7.5 \mathrm{YR} 7 / 1$ & m1f(10YR5/6) & Sandy loam & $3 \mathrm{msbk}$ & - & npsw \\
\hline \multicolumn{9}{|c|}{ Soil Type B: Profile 3: Typic Epiaquults/Ferralic Acrisols (Epidystric) } \\
\hline Ap & $0-13$ & $7.5 \mathrm{YR} 6 / 2$ & 7.5YR7/1 & & Sandy loam & $2 \mathrm{mg}$ & As & fnsw \\
\hline $\mathrm{Bt}_{1}$ & $13-52$ & $7.5 \mathrm{YR} 7 / 6$ & $7.5 \mathrm{YR} 8 / 1$ & $\operatorname{m} 2 d(10 Y R 3 / 4)$ & Sandy loam & $3 \mathrm{csbk}$ & As & mpnw \\
\hline $\mathrm{Bt}_{2}$ & $52-110$ & 7.5YR6.5/6 & $7.5 \mathrm{YR} 8 / 1$ & cld(10YR5/6) & Sandy loam & $3 \mathrm{sbk}$ & As & spsw \\
\hline $\mathrm{Bt}_{3}$ & $\begin{array}{l}110- \\
147\end{array}$ & 7.5YR5.5/8 & $7.5 \mathrm{YR} 8 / 2$ & c1f(10YR5/6) & Sandy loam & $3 \mathrm{sbk}$ & - & mpsw \\
\hline \multicolumn{9}{|c|}{ Soil Type B: Profile 4: Typic Epiaquults/Ferralic Acrisols (Epidystric) } \\
\hline Ap & $0-10$ & $7.5 \mathrm{YR} 3 / 2$ & $7.5 Y R 6 / 1$ & & Sandy loam & $2 \mathrm{mg}$ & As & npsw \\
\hline $\mathrm{AB}$ & $10-40$ & $7.5 Y R 5 / 1$ & $7.5 Y R 7 / 1$ & & Sandy loam & $2 \mathrm{msbk}$ & As & npsw \\
\hline $\mathrm{Bt}_{1}$ & $40-60$ & $77.5 Y R 7 / 3$ & $7.5 \mathrm{YR} 7 / 3$ & m1f(10YR5/6) & Sandy loam & $3 \mathrm{msbk}$ & As & spsw \\
\hline $\mathrm{Bt}_{2}$ & $60-156$ & $7.5 \mathrm{YR} 8 / 3$ & $7.5 \mathrm{YR} 8 / 3$ & m1f(10YR6/6) & Sandy clay & $3 \mathrm{msbk}$ & - & vpsw \\
\hline
\end{tabular}


Texture: $\quad 1 \mathrm{~s}=$ loamy sand, $\mathrm{sl}=$ sandy loam, $\mathrm{scl}=$ sandy clay loam, $\mathrm{c}=$ clay

Structure: $\quad 1$ = weak, $2=$ moderate, $3=$ strong; $\mathrm{f}=$ fine, $\mathrm{m}=$ medium, $\mathrm{c}=$ coarse; $\mathrm{cr}=\mathrm{crumb}, \mathrm{g}$ $=$ granular, $\mathrm{sbk}=$ subangular blocky, $\mathrm{pr}=$ prismatic, sgo $=$ single grained structureless, $\mathrm{ma}=$ massive, $\mathrm{pl}=$ platy

Mottles: $\quad \mathrm{f}=$ few, $\mathrm{c}=$ common, $\mathrm{m}=$ many; $\mathrm{f}=$ faint, $\mathrm{d}=$ distinct, $\mathrm{p}=$ prominent; $\mathrm{c} 2 \mathrm{f}=$ common medium faint, $\mathrm{m} 2 \mathrm{~d}=$ many medium distinct, $\mathrm{flf}=$ few fine faint, $\mathrm{c} 3 \mathrm{~d}=$ common coarse distinct

Consistence: $\mathrm{ssw}=$ slightly sticky wet, $\mathrm{sw}=$ sticky wet, $\mathrm{vsw}=$ very sticky wet, $\mathrm{p}=$ plastic, $\mathrm{npsw}=$ non plastic and sticky wet, $\mathrm{f}=$ friable, $\mathrm{g}=$ gritty (loose)

Horizon: $\quad \mathrm{ds}=$ diffuse $\mathrm{smoth}, \mathrm{gs}=$ gradual smooth, $\mathrm{cw}=$ clear wavy, al $=$ abrupt lobate, as $=$ abrupt smooth

\section{Horizon Designation Identity}

Ap - $\quad$ Disturbed surface layer due to cultivation or heavy traffic e.g. cattle

$\mathrm{AB} \quad-\quad$ Intermediate horizon between A-B usually possess characteristics of some A and some B

Bt - $\quad$ Accumulation of illuvial clay translocated from the upper horizons

$\mathrm{Br} \quad$ - $\quad$ Strong reduction due to presence of underground water by exhibiting mottles or black $\mathrm{MgO}_{2}$ coating

$\mathrm{Bg} \quad-\quad$ gleyed horizon. Usually signified by prismatic wedge shaped structures or presence of numerous mottles

$\mathrm{BC} \quad$ - $\quad$ Intermediate horizon between $\mathrm{B}$ and $\mathrm{C}$ horizon

$\mathrm{Bw}$ - Indicate development of colour or structure or both with little or no apparent illuviation

$\mathrm{Cg} \quad$ - $\quad$ No other pedogenic change has taken place besides gleying

White (1987), Fitzpatrick (1986), Schoeneberger et al., (1998)

Table 5: $\quad$ Physical and Chemical properties of the study area

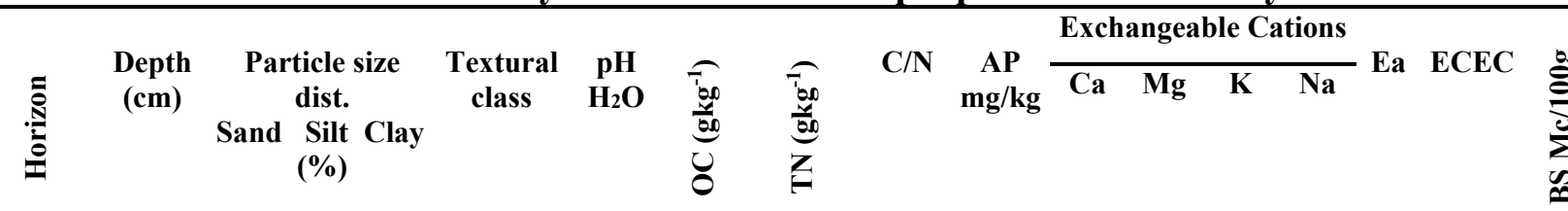

\begin{tabular}{llllllllllllllllll}
\hline \multicolumn{10}{l}{ Soil type A Profile 1: Vertic Endoaquepts/Vertic Gleysols (Orthoeutric) } \\
A & $0-12$ & 59.0 & 12.7 & 28.3 & SCL & 4.56 & 3.30 & 0.38 & 8.6 & 28.88 & 2.93 & 1.05 & 0.28 & 0.14 & 1.46 & 4.40 & 75 \\
B & $12-40$ & 56.0 & 14.1 & 29.9 & SCL & 4.41 & 2.37 & 0.21 & 11.3 & 23.00 & 2.53 & 0.88 & 0.27 & 0.13 & 1.48 & 3.81 & 72 \\
BC & $40-116$ & 55.6 & 13.2 & 30.2 & SCL & 4.53 & 2.09 & 0.14 & 14.9 & 3.40 & 1.75 & 0.63 & 0.24 & 0.10 & 1.45 & 2.72 & 65 \\
C & $116-$ & 59.4 & 9.2 & 31.4 & SCL & 4.74 & 2.97 & 0.11 & 27.0 & 3.40 & 1.63 & 0.53 & 0.22 & 0.09 & 1.41 & 2.47 & 64 \\
& 178 & & & & & & &
\end{tabular}

Soil type A Profile 2: Aeric Glossaqualfs/Lixic Gleysols (Orthoeutric)

\begin{tabular}{|c|c|c|c|c|c|c|c|c|c|c|c|c|c|c|c|c|c|}
\hline A & $0-11$ & 47.5 & 36.3 & 16.2 & $\mathrm{~L}$ & 4.62 & 3.0 & 0.28 & 10.7 & 4.13 & 3.83 & 1.00 & 0.29 & 0.12 & 1.43 & 5.24 & 78 \\
\hline $\mathrm{Bt}_{1}$ & $11-70$ & 53.1 & 18.1 & 27.8 & SCL & 4.48 & 1.9 & 0.16 & 11.8 & 2.30 & 3.23 & 0.76 & 0.22 & 0.10 & 1.48 & 4.31 & 74 \\
\hline $\mathrm{Ct}_{2}$ & $70-160$ & 57.2 & 38.1 & 30.7 & $\mathrm{SL}$ & 4.47 & 0.2 & 0.03 & 6.6 & 3.40 & 1.98 & 0.60 & 0.20 & 0.09 & 1.48 & 2.87 & 66 \\
\hline \multicolumn{18}{|c|}{ Soil type B Profile 3: Typic Epiaquults/Ferralic Acrisols (Epidystric) } \\
\hline Ap & $0-13$ & 67.1 & 23.8 & 9.1 & SL & 5.43 & 3.60 & 0.31 & 12.2 & 7.50 & 0.50 & 0.60 & 0.12 & 0.25 & 1.19 & 2.67 & 55 \\
\hline $\mathrm{Bt}_{1}$ & $13-52$ & 77.9 & 7.1 & 15.0 & SL & 5.61 & 2.37 & 0.34 & 6.9 & 4.90 & 0.36 & 0.20 & 0.10 & 0.19 & 1.14 & 1.99 & 43 \\
\hline $\mathrm{Bt}_{2}$ & $52-110$ & 71.5 & 14.0 & 14.5 & SL & 4.07 & 2.23 & 0.22 & 10.1 & 21.40 & 0.21 & 0.10 & 0.10 & 0.11 & 1.60 & 2.12 & 24 \\
\hline $\mathrm{Bt}_{3}$ & $\begin{array}{l}110- \\
147\end{array}$ & 62.9 & 19.0 & 18.1 & $\mathrm{SL}$ & 3.47 & 1.98 & 0.18 & 11.0 & 17.63 & 0.20 & 0.10 & 0.10 & 0.12 & 1.90 & 2.42 & 21 \\
\hline \multicolumn{18}{|c|}{ Soil type B Profile 4: Typic Epiaquults/Ferralic Acrisols (Hyperdystric) } \\
\hline Ap & $0-10$ & 71.0 & 20.8 & 7.2 & SL & 4.99 & 3.77 & 0.28 & 13.5 & 4.50 & 0.38 & 0.24 & 0.18 & 0.19 & 1.31 & 2.30 & 43 \\
\hline $\mathrm{AB}$ & $10-40$ & 69.0 & 25.8 & 7.8 & SL & 4.90 & 3.21 & 0.23 & 14.0 & 7.90 & 0.12 & 0.06 & 0.01 & 0.08 & 1.35 & 1.61 & 16 \\
\hline $\mathrm{Bt}_{1}$ & $40-60$ & 61.9 & 26.0 & 12.1 & SL & 5.49 & 2.63 & 0.35 & 7.50 & 1.90 & 0.07 & 0.03 & 0.01 & 0.01 & 1.19 & 1.31 & 9 \\
\hline $\mathrm{Bt}_{2}$ & $60-156$ & 49.6 & 13.3 & 36.1 & $\mathrm{SC}$ & 4.30 & 2.49 & 0.26 & 9.20 & 3.40 & 0.04 & 0.01 & 0.01 & 0.01 & 1.52 & 1.60 & 4 \\
\hline
\end{tabular}




\section{Soil Classification}

The USDA Soil Taxonomy (Soil Survey Staff, 1999) was used to classify the soils according to their morphological, physical and chemical properties. Soil type A1 was qualified as Aquept because they had endosaturation as a result of ground water. There was upward movement of water to the soil surface. At the great group level, these soils are classified as Endoaquepts. The soils were called Vertic Endoaquepts at the subgroup level due to the surface features of mild cracks generally below $1 \mathrm{~cm}$ (specified to be $5 \mathrm{~mm}$ or more) within $125 \mathrm{~cm}$ of the mineral soil surface. The high base saturation together with the presence of an argillic horizon in soil type A2 qualifies it as Alfisols. The soil had Aquic soil moisture regime due to the redoximorphic features observed in one or more horizons beyond $41 \mathrm{~cm}$ of the mineral soil surface and so called Aqualfs. These soils had Glossic horizon which developed as a result of the degradation of an argillic horizon (a soil process from which clay and free iron oxides are removed). They are called Aeric Glossaqualfs because they are wet Glossaqualfs.

Soils type B are Ultisols because they had an argillic horizon with low base saturation due to the release of bases by weathering. They are further called Aquults due to redoximorphic features in most layers between either the lower boundary of the Ap horizon or to a depth of $25 \mathrm{~cm}$ and below the mineral soil surface. These soils were qualified as Typic Epiaquults because they did not have a sandy particle size class throughout a layer extending from the mineral soil surface to the top of an argillic horizon to a depth of $50 \mathrm{~cm}$ or more.

In the World Reference Base for Soil Resources (FAO, 1990), soil type A1 qualified as Vertic Gleysols due to the cracks which open and close periodically and the base status above $50 \%$. Those of A2 were called Lixic Gleysols because of the Lixic features and argillic horizon along side with the high base status. One difference between profile 3 and 4 is the specification on their base status. While profile 3 was classified as Ferralic Acrisols (Epidystric), profile 4 was classified as Ferralic Acrisols (Hyperdystric). This is because while they are termed dystric being lower than 50 $\%$ base status between 20 to $100 \mathrm{~cm}$ in all parts from soil surface, profile 4 had less than $20 \%$ in some parts within $100 \mathrm{~cm}$.

\section{Suitability Evaluation for Rice and Sugarcane}

Land suitability involved matching of land characteristics/qualities of the study sites (Table 5) with the land requirement for sugarcane (Table 1 and 2) to evaluated suitability classes for the study site. The slope of $0-2 \%$ made all the soil units highly suitable for sugarcane. The topography will favour mechanization. The organic matter content, total $\mathrm{N}$, available $\mathrm{P}$, and CEC were low and was rated marginally suitable (S3) for sugarcane cultivation but moderately suitable (S2) for rice. The soil $\mathrm{pH}$ was acidic to slightly acidic. Regarding soil depth, all the soil profiles were favourable for rice and sugarcane production. Generally non parametric suitability evaluation of the soil types for wetland rice and sugarcane showed that sugarcane was marginally suitable (S3) for soil Type A, but rice was moderately suitable (S2) for all the 4 soil types.

\section{Summary and Conclusion}

"We can loose a battle and ultimately win the war" (Buzzard, 2006). The war for effective landuse and food security has many battle fields, one of which are wetlands. The focus on winning the war requires preserving the battle fields necessary, which in this case are wetlands. This is why encroachment into them hampers the aim of effective landuse. However, the funds committed to coastal wetlands were fund to be unimpressive by Ojanuga (2005), when he said "coastal wetland researches have provoked more food for thought than rice for food". Inland wetlands started receiving more attention with the Fadama Initiative. The pace of this success is threatened, especially in urban areas by urbanization.

Based on the morphological, physical and chemical attributes of the soils, key is the ability to retain water on the soil surface during the rains as well as below the soil surface temporarily after 
the rains or permanently, throughout the dry season. The suitability evaluation revealed that the 2 soil types generally adapted to the cultivation of wetland rice compared to sugarcane.

\section{References}

[1] Adamgbe E.M. and Ujoh F. (2013). Effect of rainfall variability on maize yield in Gboko, Nigeria. Peer Reviewed Journal of Environmental Protection (JEP). Publication of scientific research inc. Delaware, USA. September 2013, 4, 881887.

[2] Akamigbo, F.O.I. (2002). Survey Classification and Landuse of Wetland Soils in Nigeria. Proceedings of the $27^{\text {th }}$ Annual conference of the Soil science Society of Nigeria pp. 1-9

[3] Ayolagha, G.A. and Opene, G.A. (2012). Characterization and Classification of Selected Soils of Ndoni in the Meander Belt of Niger Delta. Nigerian Journal of Soil Science Vol. 22 (2) 54p

[4] Bennetta, J.G., Blain Rains, A. Gosden, P.N. Howard, W.J., Hutcheon, A.A. Kerr, W.B. ansfield, J.E. Radihem, L.J., and Wood A.W. (1978). Land Resources of Central Nigeria. Vol. 4b, the Benue Valley. Land Resources Study 29. (Ed. I.D. Hill). Land Resource Development Centre, M.O.N., Tolworth Tower, Surbiton England. P64 - 87

[5] Brady N.C and R. R. Weil, (2002). The Nature and Properties of Soils, Prentice-Hall, Upper Saddle River, NJ, USA, 13th edition

[6] Brady, N.C and Weil, R.R. (2014). The Nature and Properties of Soils, $14^{\text {th }}$ ed. Prentice Hall. New Jersey, USA. 960pp.

[7] Day, P.R. (1965). Particle fraction and particle size analysis. In: C.A. Black (ed), Methods of Soil Analysis, Agron. 9. ASA, Madison, Wisconsin, USA, Pp547-577

[8] Esu, I.E. (1999). Fundamentals of Pedology. Stirling-Hordem Publshers (Nig.) Ltd. Lagos, Ibadan, Benin City. Jattu-Uzaire, 138 pp

[9] Etteh Aro (1984). Final Draft Report Vol. 1 of the Semi-Detailed Soil Survey of the Lower Benue Flood Plains Phase two. P202 - 208

[10] FAO, (1983). Guidelines: Land Evaluation for Rainfed Agriculture. FAO Soil Bulletin 52. FAO, Rome 237p.

[11] FDALR (1990). Federal Department of Forestry Vegetation Maps. NC. 32-13, NC 32-14, NB 32-1, NB 32-2. Land Resource Report 7.ministry of Overseas Development. Land Resource Division

[12] Foth H.D. (1990). Fundamentals of Soil Science, JohnWiley and Sons, New York, NY, USA, 8th edition.

[13] Franzmeier, D.P., Yahner, J.E., Stainhardt, G.C. and Sinclair, H.R. (1983). Cour Patterns and Watertable Levels in some Indiana Soils. Soil Science Society of American Journal. 47:11961202

[14] Hame, T., Beilfuss, K., O’ Brien E., Kilmer, S., Pescitelli, S. and Magyera, K.(1914). Land Use and Wetlands. 20 $0^{\text {th }}$ Anniversary Wetland Conference. 214N. Hamilton St. No. 201 Madison, WI 53703 (608) 250-9971. November $14^{\text {th }}$ wisconsinwetlands.org

[15] Hesse, R.P. (1971). A text book of soil chemical analysis. John Murray Publishers Ltd., London. Pp8-184

[16] Idoga, S. and Azagaku, E.D. (2005). Characterization and Classification of soils of Janta area Plateau State Journal Vol. 15:116-122

[17] Isirimah, N.O. (2002). Understanding Telematology and their Functions for Effective Management of Wetlands of the Niger Delta Region of Nigeria. Proceedings of the $27^{\text {th }}$ Annual Conference of the Soil Science Society of Nigeria pp.254-267 
[18] Kang, B.T. and Balasubramanian, V. (1990). Long-term fertilizer trials in Alfisols in West Africa. In Transactions of XIV International soil science study congress, Kyoto, Japan (vol. 4) Kyoto, Japan: ISSS.

[19] Kang, B.T. (1993). Changes inn Soil Chemical Properties and Crop Performance with Continuous Cropping on an Entisol in the Humid Tropics. In Mulongoy, K. and R. Merckx (eds) Soil Organic Matter and Sustainability of Tropical Agriculture: John Willey and Sons (UK), KU Lenven (Belgium) and IITA (Nigeria) pp 297-305

[20] Krasilini-Koff, G., Gahoonia, T.S. and Nielsen, N.E. (2002). Rice Products in the subtropical Africa Wet land Soils

[21] Landon, J.R. (1984). Booker Tropical Manual. A Handbook for Soil Survey and Agricultural Land Evaluation in the Tropics and Subtropics. Booker Agricultural International Ltd. UK.

[22] Malgwi, W.B. (1979). A study of soils in the high plains of Hausa Land, Samaru, Zaria Nigeria. M.Sc Thesis, Department of Soil Science A.B.U. Zaria, Nigeria. 126p

[23] Miura, K., Badayos, R.B. and Briones, A.M. (1997). Characteristics of Soils of Iowland areas in the Philippines with Special reference to Parent Materials and climatic conditions JIRCASJ, 5, 31-42

[24] Odingo, R.S. (1991). Research and Development of Land Use Policies in Africa. Paper Presented for the United Nations University Project on the Institute of National Resources in Africa (UNUINRA) Nairobi Kenya

[25] Offodile, M.E. (1974). A Review of Geology of the cretaceous Benue Valley. Kogbe C.A. (ed). The conference on the Geology of Nigeria. Obafemi Awolowo University Ile-Ife. Elizabethan Publishing Co. Box 174 Surelere (Lagos) Nigeria

[26] Ojanuga, A.G. (2005). Management of Fadam Soils for Food Security and Poverty Alleviation. $30^{\text {th }}$ Annual Conference of Soil Sciece Society of Nigieria $5^{\text {th }}-9^{\text {th }}$ December, pp $1-10$

[27] Peech, M. (1965). Exchange Acidity. In: C.A. Black (ed) methods of Soil Analysis Part 2 chemical and mineralogical properties. No. 9 in the series Agronomy. American Society of Agronomy. Inc. Publisher Madison, Wisconsin USA. 905-913

[28] Soil Survey Staff (1999). A Basic System of Soil Classification for making and Interpreting Soil Survey. Second Edition. Soil Survey Staff.

[29] Ufot, U.O. (2012). Soils and the Environment for Colleges and Universities, Shadow Publishers Ltd, Owerri, Nigeria 1634p. 